\title{
The application of pigment-protein fraction from Nannochloropsis oculata on $\beta$-actin response of Cromileptes altivelis infected with viral nervous necrosis
}

\section{Aplikasi fraksi protein pigmen Nannochloropsis oculata terhadap respons $\beta$-aktin pada ikan kerapu tikus yang diinfeksi viral nervous necrosis}

\author{
Uun Yanuhar ${ }^{1 *}$, Achmad Khumaidi ${ }^{2}$ \\ ${ }^{1}$ Laboratorium Ilmu-Ilmu Perairan dan Bioteknologi, FPIK, Universitas Brawijaya, Malang \\ ${ }^{2}$ Akademi Perikanan Ibrahimy, Situbondo, Indonesia \\ *E-mail: uunyanuhar@yahoo.com
}

\begin{abstract}
$\beta$-actin is a prominent protein in the immune system. An outcome from gene transcription, the protein protects against pathogen infection, such as receptor clustering, antigen internalization, and regulating vesicle for antigen processing. $\beta$ - actin expression will determine the success of immune response of the organism. This study aimed to understand the role of pigment-protein fraction (PPF) from Nannochloropsis oculata in the increase of $\beta$-actin expression in humpback grouper Cromileptes altivelis infected by viral nervous necrosis (VNN). The experiment was performed with one negative control (A: normal fish) and three PPF treatments (B: fish + PPF, C: fish + VNN, and D: fish + PPF + VNN). PPF was applied through the sonde method and analyzed with immunohistochemistry technique and Immunoratio software. The results showed that PPF was able to increase $\beta$-actin expression on all treatments: A (34.9\%), B (38.1\%), C (39.1\%), and D (51.6\%). It demonstrated PPF ability to induce the increase of $\beta$-actin expression indicating an improved defense of humpback grouper $C$. altivelis against VNN infection.
\end{abstract}

Keywords: $\beta$-actin, pigment-protein fraction, Nannochloropsis oculata, VNN

\begin{abstract}
ABSTRAK
$\beta$-aktin adalah protein yang berfungsi penting sebagai salah satu sistem pertahanan tubuh. Protein ini merupakan hasil transkripsi dari gen yang memiliki fungsi penting dalam sistem pertahanan tubuh terhadap infeksi patogen, seperti kelompok reseptor, internalisasi antigen, dan mengatur keluar masuknya vesikel untuk pemrosesan antigen. Ekpresi $\beta$-aktin menjadi penentu berhasil atau tidaknya respons imun pada tubuh organisme. Penelitian ini bertujuan untuk mengetahui peran fraksi protein pigment (FPP) dari Nannochloropsis oculata dalam meningkatkan respons $\beta$-aktin pada ikan kerapu tikus Cromileptes altivelis yang terinfeksi viral nervous necrosis (VNN). Pengamatan dilakukan pada empat percobaan yaitu, satu kontrol (A : ikan normal) dan tiga perlakuan FPP (B : ikan + FPP, C: ikan + VNN, dan D: ikan + VNN + FPP). Pemberian FPP menggunakan metode stoned dan analisis hasil penelitian menggunakan teknik imunohistokimia dan Immunoratio. Hasil penelitian ini menunjukkan bahwa pengiduksian FPP mampu meningkatkan ekpresi $\beta$-aktin yaitu A (34,9\%), B (38,1\%), C (39,1\%), dan D (51,6\%). Hal tersebut menunjukan FPP mampu menjadi inducer yang baik untuk peningkatan ekpresi $\beta$-aktin. Meningkatnya ekspresi $\beta$-aktin bisa dijadikan sebagai indikator pertahanan tubuh ikan kerapu tikus $C$. altivelis terhadap infeksi VNN.
\end{abstract}

Kata kunci: $\beta$-aktin, fraksi protein pigmen, Nannochloropsis oculata, VNN

\section{INTRODUCTION}

The humpback grouper is one of the most important commodity in Indonesian aquaculture due to its high economic value, priced up to Rp34,000,000 for 2015 export starting at $\mathrm{Rp} 500,000,-/ \mathrm{kg}$ from the farmers (Ariyanti, 2015). The high price drive farmers to start culturing this fish, albeit they are faced with several challenges in the process. The biggest challenge in a humpback grouper culture is the intracellular parasite or virus. Viral nervous necrosis (VNN) contribute a large portion of the failure of humpback grouper culture. It is capable of causing tissue damage, hyperplasia, necrosis, vacuolation and high mortality up to $100 \%$ 
(Yuwanita \& Yanuhar, 2013). This virus infected early stages of larvae and juveniles focusing on the eye and brain nerve system with distinctive symptoms such as whirling, sleeping sickness, and abnormal behavior.

Regulation of immune system mechanism is vital for the success against VNN infection. One of the protein with significant function of the immune system is $\beta$-actin (Jönsson et al., 2012). This protein is a cytoskeleton component which functions to regulate cell morphology, receptor clustering, antigen internalization, and regulating vesicle for antigen processing. A deficiency in cytoskeleton actin regulation will cause a disturbance in immunological synapse formation, the activation of $\mathrm{T}$ and $\mathrm{B}$ cells (Yuseff and Reversat, 2011). Furthermore, $\beta$-actin is also involved in an important nucleus mechanism e.g. transcription, mRNA export, and chromatin renovation (Zheng et al., 2009; Spencer, 2011). In the nucleus, $\beta$-actin binds with RNA polymerase II and III (Tang et al., 2009; Spencer, 2011).

Nannochloropsis oculata is a single cell microalgae containing pyrenoid and numerous pigments with anti-bacterial and anti-viral properties, namely chlorophyll a, $\beta$-carotene, violaxanthin, and veucherxanthin (Cao et al., 2013). N. oculata is also rich on nutritional value of the following: protein $52.11 \%$; carbohydrate $16.00 \%$, and lipid $27.64 \%$ consisting of eicosapentaenoic acid (EPA) up to $31.42 \%$ and $3.94 \%$ arachidonic acid (ARA/AA) (Bentley et al., 2008). In vivo test of carotenoid feeding has proven to increase fish immune system by modulating NK cells, which have a cytotoxic effect on virus infected cells (Male et al., 2012).

This study used pigment protein fraction (PPF) from $N$. oculata which acted as an inducer, a compound activating $\beta$-actin, specific genes in protein expression. This particular protein played a role in increasing the humpback grouper $C$. altivelis immune system against VNN infection. The inducing effect is highly dependent on the target cell's ability to recognize the inducer as a protein molecule (Ringo et al., 2011). Therefore, this study was aimed to understand the role of pigment-protein fraction (PPF) in increasing $\beta$-actin response on humpback infected VNN.

\section{MATERIALS AND METHODS}

\section{Experimental design}

This study used descriptive experimental design dividing the fish into four groups, A: negative control (grouper fed with normal feed/ no PPF and viral infection); B (fish + PPF): the grouper was fed and given PPF based on the body weight; $\mathrm{C}($ fish $+\mathrm{VNN})$ : the grouper was fed and infected with VNN corresponding to its body weight, infection was conducted by giving feed mixed with VNN positive fish; D (fish + FPP $+\mathrm{VNN}$ ): the grouper was treated with PPF and infected with VNN.

\section{Pigment protein fraction (PPF) isolation from Nannochloropsis oculata}

$N$. oculata used in this study was acquired from BBAP Situbondo, filtered until $150 \mathrm{~g}$ wet paste was obtained. The isolation method referred to Yanuhar (2015), where the cells were homogenized in a mortar for one hour with liquid nitrogen addition. $8 \mathrm{~mL}$ from 50 $\mathrm{mM}$ glycine and $20 \mathrm{mM} \mathrm{KCl}(\mathrm{pH} 7.5)$ were added then centrifuged at $12,000 \mathrm{rpm}$ for 60 min at $4{ }^{\circ} \mathrm{C}$ temperature. The supernatant was then added to solid ammonium sulphate (SAS) solvent gradually to get a final concentration of $30 \% \mathrm{v} / \mathrm{v}$ and centrifuged was performed at $15.000 \mathrm{rpm}, 4{ }^{\circ} \mathrm{C}$ for $30 \mathrm{~min}$. A dialysis bag was sterilized by boiling in 0.1 mMTris-EDTA ( $\mathrm{pH}$ 7.3) for ten min. Sample of $2,000 \mathrm{~mL}$ was treated with dialysis using 20 mMTris- $\mathrm{HCl}, \mathrm{pH} 8,0$ for 24 hours at $4{ }^{\circ} \mathrm{C}$ temperatures with continuous mixing. Afterwards, the sample was filtered by amillipore filter $(0.22 \mu \mathrm{m}$, Sartorius). The dialysis and filtration process were repeated once. Protein content was then measured using a nanodrop spectrophotometer (NanoDrop Technology, Wilmington, USA) at $280 \mathrm{~nm}$. One absorbance corresponds with $1 \mathrm{mg} / \mathrm{mL}$ protein.

\section{PPF in-vivo test on humpback grouper}

In this study PPF was given to the fish from the first day of rearing, while VNN infection was conducted on day 14. PPF was given earlier to monitor its activities in enhancing fish immune system. Thus, it is expected that when challenged against VNN the immune system would be ready prepared for the infection.

Prior to treatments, fish were acclimatized for one week. On treatments B, C, and D, PPF was given with sonde method for six times on day $1,5,9,14,19$, and 24; each application dosage was adjusted to fish body weight at $306 \mu \mathrm{L}, 315$ $\mu \mathrm{L}, 322 \mu \mathrm{L}, 326 \mu \mathrm{L}, 345 \mu \mathrm{L}$, and $351 \mu \mathrm{L}$. On treatment $\mathrm{D}, \mathrm{VNN}$ infection was performed using VNN positive fish meat mixed with fresh feed and fed ad libitum on day-14, 19, and 24. On day- 
27 the target organ, which was the main part of the central nervous system was removed through dissection.

\section{Brain isolation of humpback grouper}

On the organ isolation process, post in vivo test fish was sedated with clove oil at $2 \mathrm{~mL}$ per 10 $\mathrm{L}$ seawater. When the fish was unconscious, it is dissected and the brain was removed. Then it was immersed in liquid nitrogen and preserved in the liquid nitrogen tank.

\section{Protein analysis with sodium dodecyl sulfate} polyacrylamide gel electrophoresis (SDS Page)

Protein analysis was conducted with SDSPage Laemmli electrophoresis (Laemmli, 1970). The electrophoresis gel used was sodium dodecyl sulfate polyacrylamide gel with $12.5 \%$ concentration. Analysis was conducted by adding the buffer sample into protein sample (1:1 ratio) in an eppendorf tube and heated at $100{ }^{\circ} \mathrm{C}$ temperature for five min in $5 \mathrm{~mm}$ Tris $\mathrm{HCl}$ solvent at $\mathrm{pH} 6.8 ; 5 \%$ 2-mercapto ethanol; $2.5 \% \mathrm{w} / \mathrm{v}$ sodium dodecyl sulfate, and $10 \% \mathrm{v} / \mathrm{v}$ glycerol. It was then cooled and kept at $20{ }^{\circ} \mathrm{C}$ until further analyses. Analysis was performed at a constant current $20 \mathrm{~mA}$ for $40-50 \mathrm{~min}$ or the tracking dye was $0.5 \mathrm{~cm}$ from the gel bottom. Then, the sample was dyed with commasie brilliant blue. The last step was de-staining to remove gel colorant and emphasize the protein band.

\section{Immunohistochemistry}

Immunohistochemistry dye was used in accordance to a study by Khan et al. (2014). VECTASTAIN ${ }^{\circledR}$ ABC kit (ABC-Elite, Santa Cruz, Vector Laboratories) was used to detect biotin using chromogen (diaminobenzidine tetrachloride). Tissue sample was dehydrated with alcohol and cleaned with xylene. Peroxidase endogenous enzyme was cooled with $3 \%$ hydrogen peroxide and methanol at room temperature for $30 \mathrm{~min}$ in no light condition. The microwave antigen was retrieved with $0.01 \mathrm{~mol} / \mathrm{L}$ Sodium citrate buffer ( $\mathrm{pH}$ 6.0) then incubated in antibody monoclonal $\beta$-actin (AC-15) for 16 hours at $4{ }^{\circ} \mathrm{C}$ with 1:1,000 dilution. Afterwards, the secondary antibody biotin conjugated anti-IgG was added for $30 \mathrm{~min}$ at room temperature.

\section{Immunohistochemistry analysis}

$\beta$-actin profile can be visualized using the immunohistochemistry (IHC) method. In this study, IHC was used to examine the $\beta$-actin profile on brain related to antigen and antibody bonds. Indirect method was used with the primary and secondary antibody. The primary antibody was the monoclonal $\beta$-actin (AC-15) while the secondary was IgG antimouse conjugated protein.

Immunohistochemistry result was visualized using Olympus microscope. It was then analyzed using Immunoratio (IR) online software (Tuominen et al., 2010) to determine the percentage of $\beta$-actin expression showed as various colors. ImageJ software was also used to analyze the target gene ( $\beta$-actin) intensity as previously demonstrated by Varghese et al. (2014). Histogram scoring was based on pixel intensity, where 0 represent the darkest color while 255 represent the color white. This range was divided into four zones: 0-60 strong positive, 61-120 positive, 121-180 weak positive, and 181-255 negative.

\section{Antibody response confirmation with Western blotting}

Further analysis with Western blot method was performed to confirm $\beta$-actin expression on fish brain. In this study, a specific antibody, anti$\beta$-actin was used to confirm the presence of the target gene or protein ( $\beta$-actin) in the sample. The Western blotting analysis was performed based on the Towbin method (1979). Gel was placed on a nitrocellulose paper using semi-dry blotter from biorad after the protein analysis with SDS-Page. The electricity current used in this process was $300 \mathrm{~mA}$ for $30 \mathrm{~min}$. Then, the sample was dyed with ponceau $2 \%$ containing $3 \%$ trichloracetic acid (TCA) to detect protein movement to the nitrocellulose paper and marked to determine its molecular weight. The nitrocellulose paper was then cut following the well pattern. $\mathrm{T}$

To remove the dye, it was rinsed with $\mathrm{dH}_{2} \mathrm{O}$ and blocked with TBE (Tris/Borate/EDTA) (contains 3\% albumin) at $\mathrm{pH} 7.4$ added with $1 \%$ bovine serum albumin (BSA) and shaken for two $\mathrm{h}$. The sample was rinsed again twice at five min interval using TBE $\mathrm{pH} 7.4$ solvent containing $0.05 \%$ Tween 20 . Then secondary antibody anti fish $\operatorname{IgG}$ mice was added with $1 / 1.000$ concentration to TBE pH 7.4 and BSA 1\%, which was protected from rays' influence. The sample then shaken for two hours and underwent two five-min rinsing processes with TBE $\mathrm{pH} 7.4$ Tween $200.05 \%$. Tablet Cip diluted in $\mathrm{H}_{2} \mathrm{O} 10 \mathrm{~mL}$ was used as staining material. The solution then poured into nitrocellulose paper and observed for the appearance of red color. If the reaction was 
sufficient with $\mathrm{H}_{2} \mathrm{O}$ rinsing, drying process was continued with filter paper.

\section{Data analysis}

Data analysis was performed with descriptive quantitative method by describing the results and quantifying immunohistochemistry analysis result with immunoratio software.

\section{RESULTS AND DISCUSSION}

\section{Result}

Nannochloropsis oculata PPF analysis

PPF isolation result using SDS-Page method is presented in Figure 1. Based on molecular weight identification above, it was indicated that $N$. oculata microalgae contained violaxanthin chlorophyll protein (VCP) and peridinin chlorophyll protein (PCP). The indication was
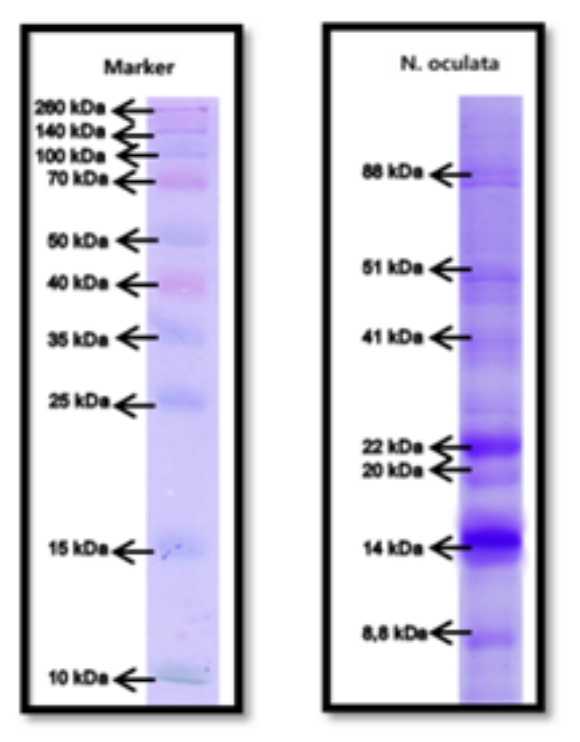

Figure 1. SDS-Page pigment-protein fraction result based on several previous microalgae protein researches which concluded protein with molecular weight of $22 \mathrm{kDa}$ was VCP (Sukenik et al., 1992; Basso et al., 2014), and of $14 \mathrm{kDa}$ was PCP (Weis et al., 2002).

\section{Humpback grouper brain's protein profile}

Protein profile analysis result using SDS-Page showed that there were protein profile differences in each treatment (Figure 2). Different expressions emerged from each treatments in Figure 2 showed different responses on fish test samples. The focus in this research was $\beta$-actin protein. Jovčevska et al. (2014) stated that $\beta$-actin molecular weight was $42 \mathrm{kDa}$. According to Figure 2, there was a protein band with molecular weight of $42.4 \mathrm{kDa}$. That finding became an early indication of $\beta$-actin expression existence from fish brain samples in every treatment.

Observation result is presented in Figure 3. According to Figure 3, it was concluded that $\beta$-actin was expressed in every treatment. The result also showed that fish expressed $\beta$-actin in normal circumstances.

\section{$\beta$-actin profile in control fish}

$\beta$-actin profile observation was also performed in the group of control fish. The result would be a standard $\beta$-actin profile to be compared to other treatments shown in the Figure 4. On the control fish group, the fish brain was in a normal condition shown by normal tissue cells (Figure 4b). IR analysis on treatments were shown with DAB value of $34.9 \%$ (Figure $4 a$ ). The percentage showed that $34.9 \%$ target gene $(\beta$-actin) on the control fish was detected, indicated with an orange color which confirmed antigen and antibody bond.

Table 1. PPF of Nannochloropsis oculata identification based on protein molecular weight

\begin{tabular}{ccc}
\hline Sample's molecular weight $(\mathrm{kDa})$ & Molecular identification & Reference \\
\hline 88.3 & - & - \\
51.2 & - & - \\
41.5 & - & Sukenik et al., 1992; \\
22.1 & violaxantin chlorophyll protein & Basso et al., 2014 \\
20.4 & (VCP) & - \\
14.6 & peridinin chlorophyll protein (PCP) & Yanuhar, 2011; Komariyah, 2014; \\
8.8 & - & Weis et al., 2002; \\
\hline
\end{tabular}



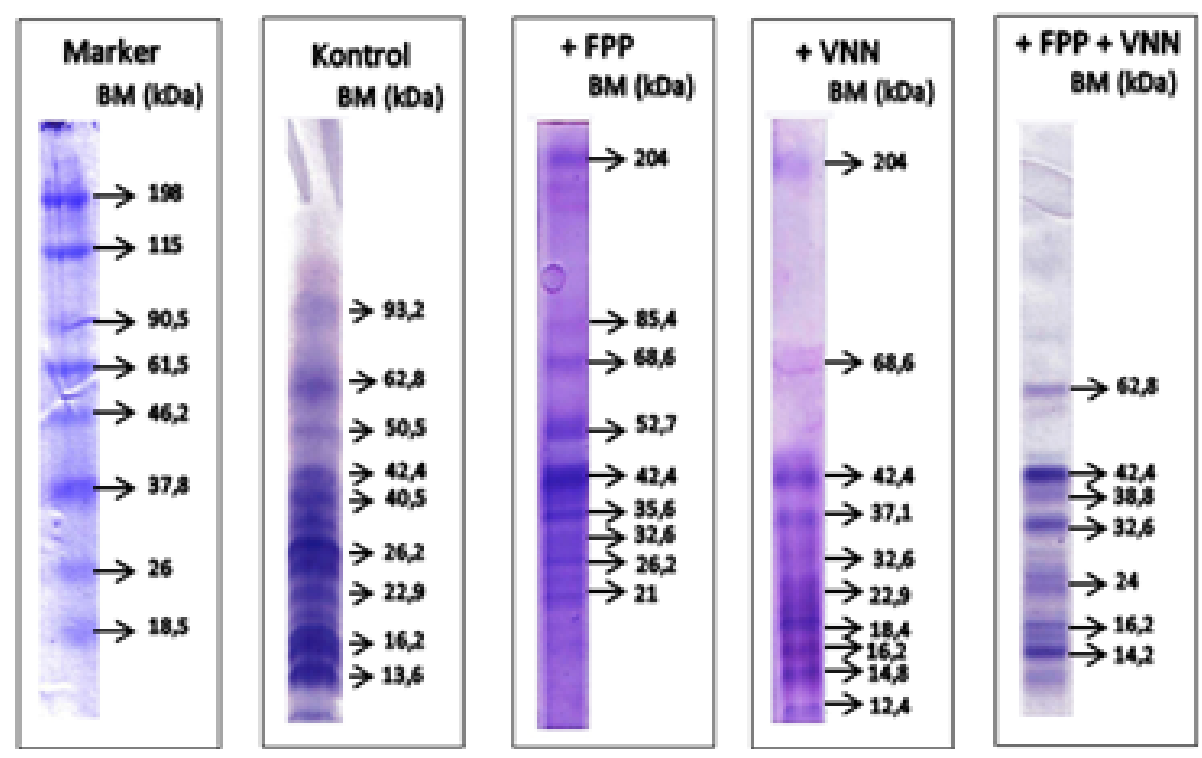

Figure 2. Humpback grouper brain protein profiles using SDS-Page

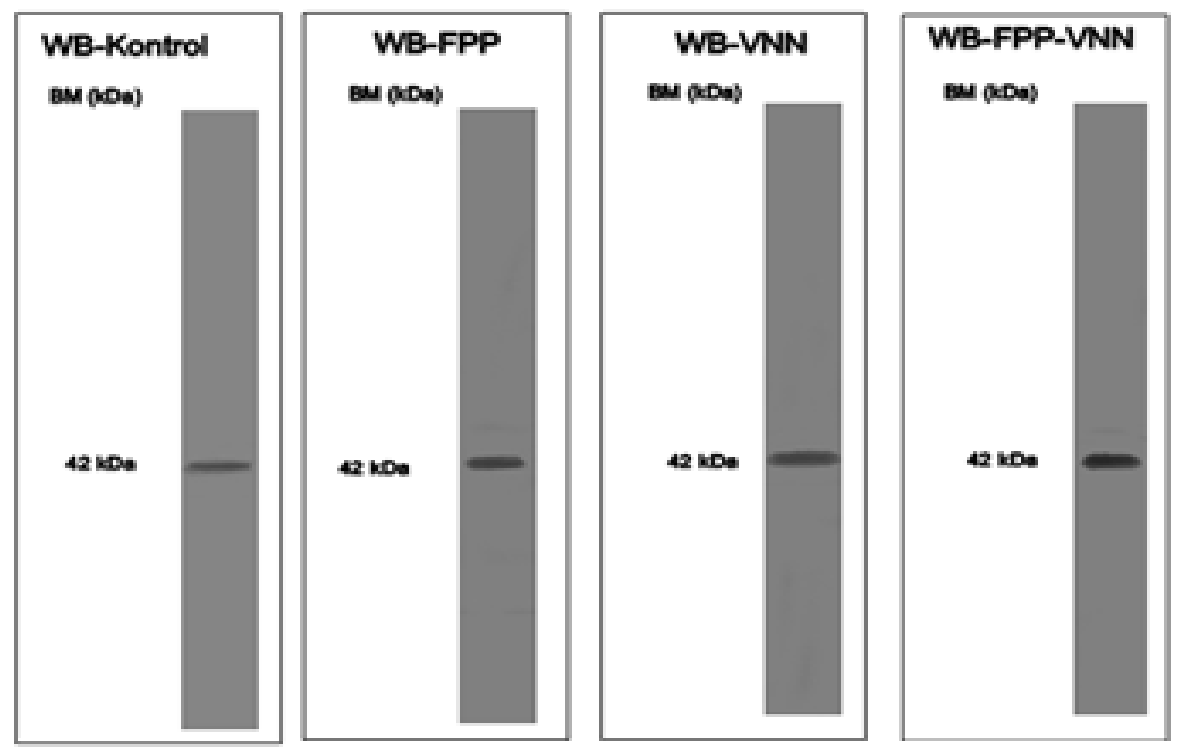

Figure 3. $\beta$-actin profile in humpback grouper brain using Western blot method

Figure $4 \mathrm{~b}$ also showed that $\beta$-actin was expressed at cell membrane and cytoplasm. It could be seen that normal fish also express $\beta$-actin. Figure $4 \mathrm{c}$ is a brain histogram showing the intensity of target gene appearance. Also, it showed that the target gene was categorized as strong positive within 50-60 range point.

\section{$\beta$-actin of PPF induced brain organ}

Upon PPF induction, the brain showed a difference compared to those of the control fish (Figure 5). On Figure 5a the distinct brownish yellow color indicates a bond between antigen and antibody. Image analysis with Immunoratio showed a value of $38.1 \%$ (Figure $5 \mathrm{~b}$ ). The number explained that $38.1 \% \beta$-actin is expressed on fish treated with PPF. The histogram analysis (Figure $5 \mathrm{c})$ also showed that the highest color intensity was $58-65$, categorized as positive.

\section{$\beta$-actin of brain organ infected with VNN}

Immunohistochemistry observation in this study confirmed that VNN infection on humpback grouper has a capability to cause cell and tissue damage. Visualization on VNN infected organ was provided in Figure 6. The damage in cell and tissue comprise of vacuolization (black arrow) and necrosis (yellow arrow) (Figure 6a). In Figure $6 \mathrm{~b}$, some cells were reduced and shrunk (green arrow) indicating apoptosis, severe cell damage 

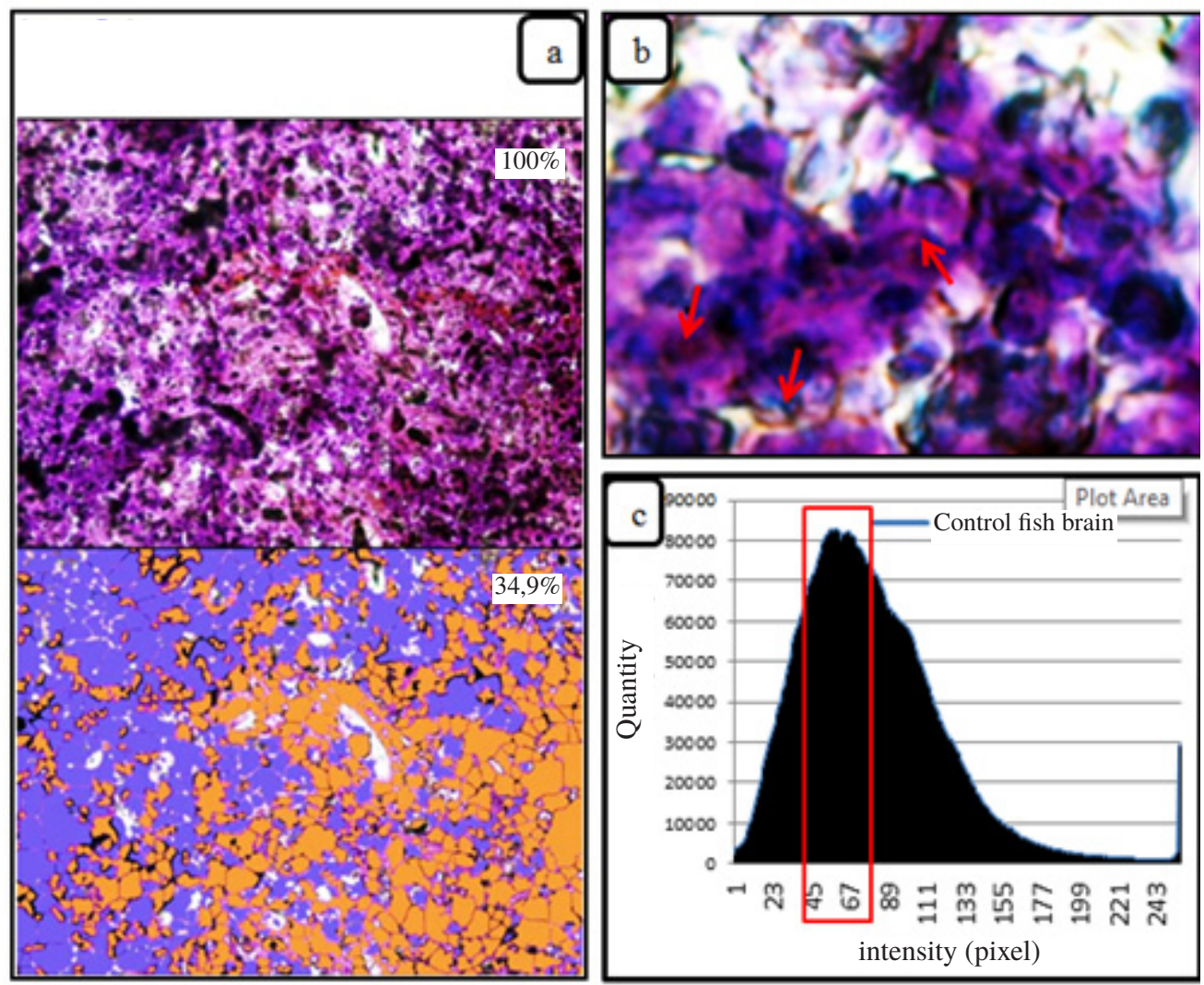

Figure 4. Control humpback grouper brain profile: (a) immunoratio (34,9\%), (b) immunohistochemistry (IHC) result, (c) histogram (ImageJ). Note: arrows indicate $\beta$-actin expression.
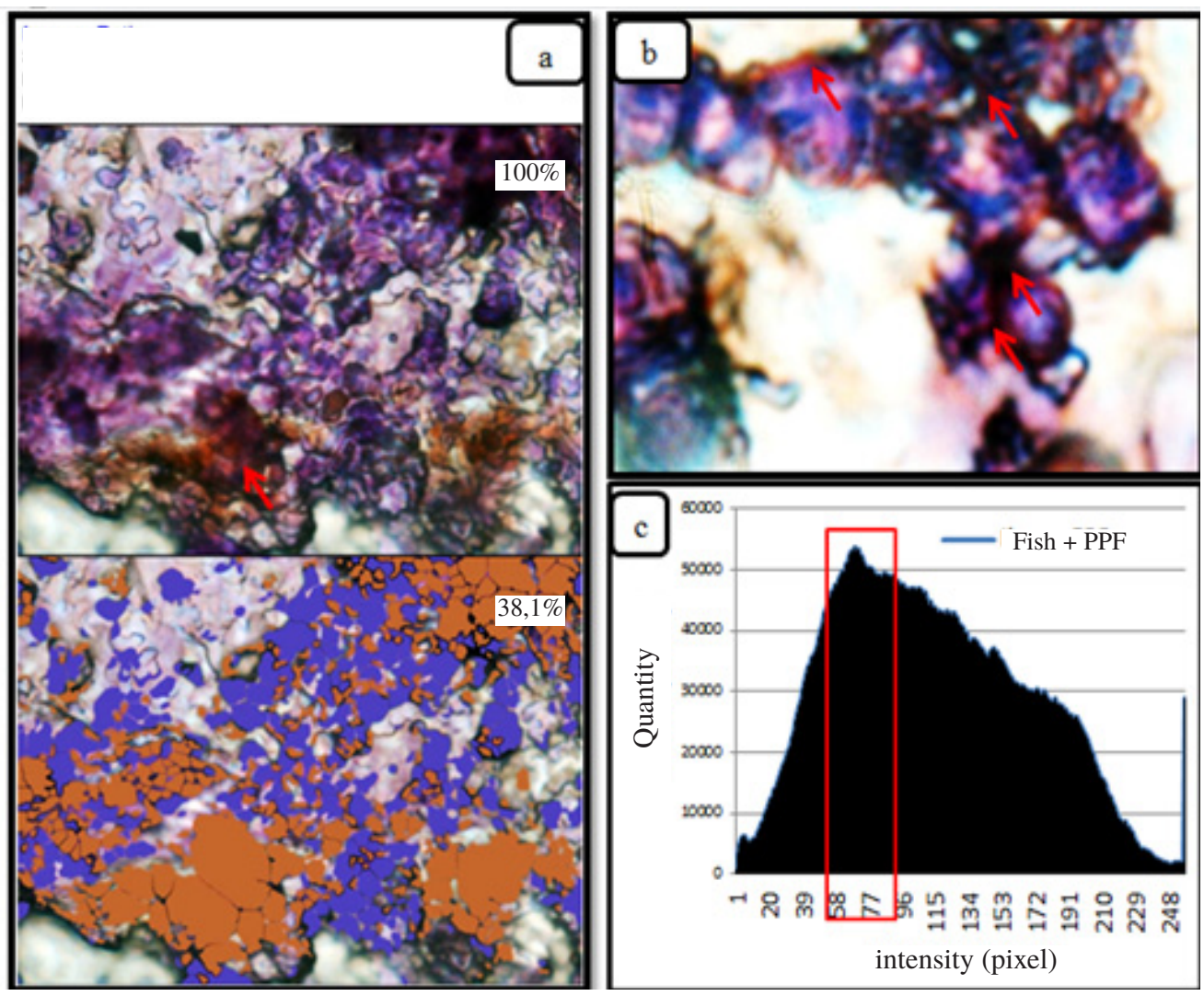

Figure 5. Humpback grouper brain profile with pigment protein fraction application: (a) immunoratio (38.1\%), (b) immunohistochemistry (IHC) result, (c) histogram (ImageJ); note: arrows indicate $\beta$-actin expression. 
that are no longer repairable. Immunoratio analysis (Figure 6a) showed a $\beta$-actin percentage of $39.1 \%$. $\beta$-actin was also expressed at a small intensity on membrane and cytoplasm (Figure $6 b)$, while histogram analysis displayed a positive category in target gene intensity with the highest value of 61-64.

\section{$\beta$-actin of PPF induced and VNN infected brain organ}

The fish died after two weeks when infected with virus but survived until the end of experiment when PPF was applied prior to VNN infection. IHC analysis also showed an increase in $\beta$-actin expression compared to control at $51.6 \%$ (Figure $7 \mathrm{a})$. Figure $7 \mathrm{~b}$ displayed $\beta$-actin on almost every cell part, membrane, cytoplasm, and nucleus. Histogram in Figure 7c also showed target gene intensity in the strong positive group at 31-44.

\section{Discussion}

$\beta$-actin is a central component for body cellular mechanism within the organism. Based on gene function, it is regarded as the internal cell regulating gene (Pollard \& Cooper, 2009). This gene has a vital role in immune system against pathogen infection, namely receptor clustering, antigen internalization, and regulating vesicle for antigen processing.

One of the natural ingredient that can be used to manage the humpback grouper health is N. oculata (Yanuhar, 2009; Yanuhar et al., 2011; Yanuhar et al., 2012) which contain PPF as anti viral and bacterial agents. When induced to $C$. altivelis brain, PPF gave a significant effect on $\beta$-actin expression. Observation at $\beta$-actin expression on $C$. altivelis brain increased from the negative control (34.9\%), FPP induced (38.1\%), VNN infected (39.1\%), to FPP induced and infected with VNN (51.8\%). The increase indicated an effective immune response from the fish. VNN infection itself has been a serious problem for humpback grouper culture due to its capability to cause cell and tissue damage (Yanuhar et al., 2012; Yuwanita \& Yanuhar, 2013; Costa \& Thompson, 2016).

The experiment showed an increase in $\beta$-actin expression when being induced with PPF. Fish respond to VNN by escalating $\beta$-actin expression to organize and proliferate immune system to face virus infection. PPF role as inducer and biocatalyst for immune system development were enhanced with the increasing $\beta$-actin expression. Said increase is possible through the violaxanthin chlorophyll protein (VCP) and peridinin chlorophyll protein (PCP) in the microalgae. The proteins are available as enzymes and function as biocatalyst in physiological response development and are categorized as carotenoid (Takaichi, 2011).

$\beta$-actin was expressed in every treatment during the experiment. As a promoter gen element, it was constitutively expressed in all the cells. The expression gave a preview of better and faster immune response. This is partly due to $\beta$-actin housekeeping characteristic, which in normal condition was also used by the cells for cell growth, migration, and survival (Bunnel et al., 2011).

The increase in gene expression indicate an effective cellular defense mechanism within the fish body. Antigen presenting cell (APC) is one of the key components in fish immune system, covering a wide range of cells including the $\mathrm{B}$ cells. On the B cells, $\beta$-actin remodeling will change its morphology enabling it to easily capture antigen (Brezski \& Monroe, 2007). $\beta$-actin also function in regulating MHC (major histocompatibility complex) molecule movement to cell membrane (Khumaidi et al., 2015). MHC is a vital component in $\mathrm{T}$ cell activation. Deficiency in $\beta$-actin expression will lower MHC presentation which eventually reduce antigen presentation to the T cells (Vascotto et $a l ., 2007)$. Actin remodeling is also essential for the macrophage and dendritic cells to help in motility, phagocytosis, and antigen presentation.

A rise in $\beta$-actin expression also increases the function of cell wall receptor in detecting antigen signal and presentation. A previous study by Komariyah (2014) on PCP application in $C$. altivelis resulted that $\mathrm{PCP}$ is capable of increasing toll-like receptor (TLR) expression. TLR has a role in capturing and sending downstream signal to receive a specific response (West et al., 2004). The signal transmitting mechanism is affected by the presence of $\beta$-actin. Also, the receptor signal absorption was also affected by actin cytoskeleton bundle (Irving et al., 2012).

PCP has been applied in inducing antivirus gene on $C$. altivelis as P56/ISG56, which is capable of blocking VNN protein synthesis. To maintain its function, P56/ISG56 depends on an effective regulation from cytoskeleton actin. PPF application on humpback grouper specifically regulate TNF and IL-6 expression indicating an increase in fish immune. The expression of antivirus genes and cytosine is 


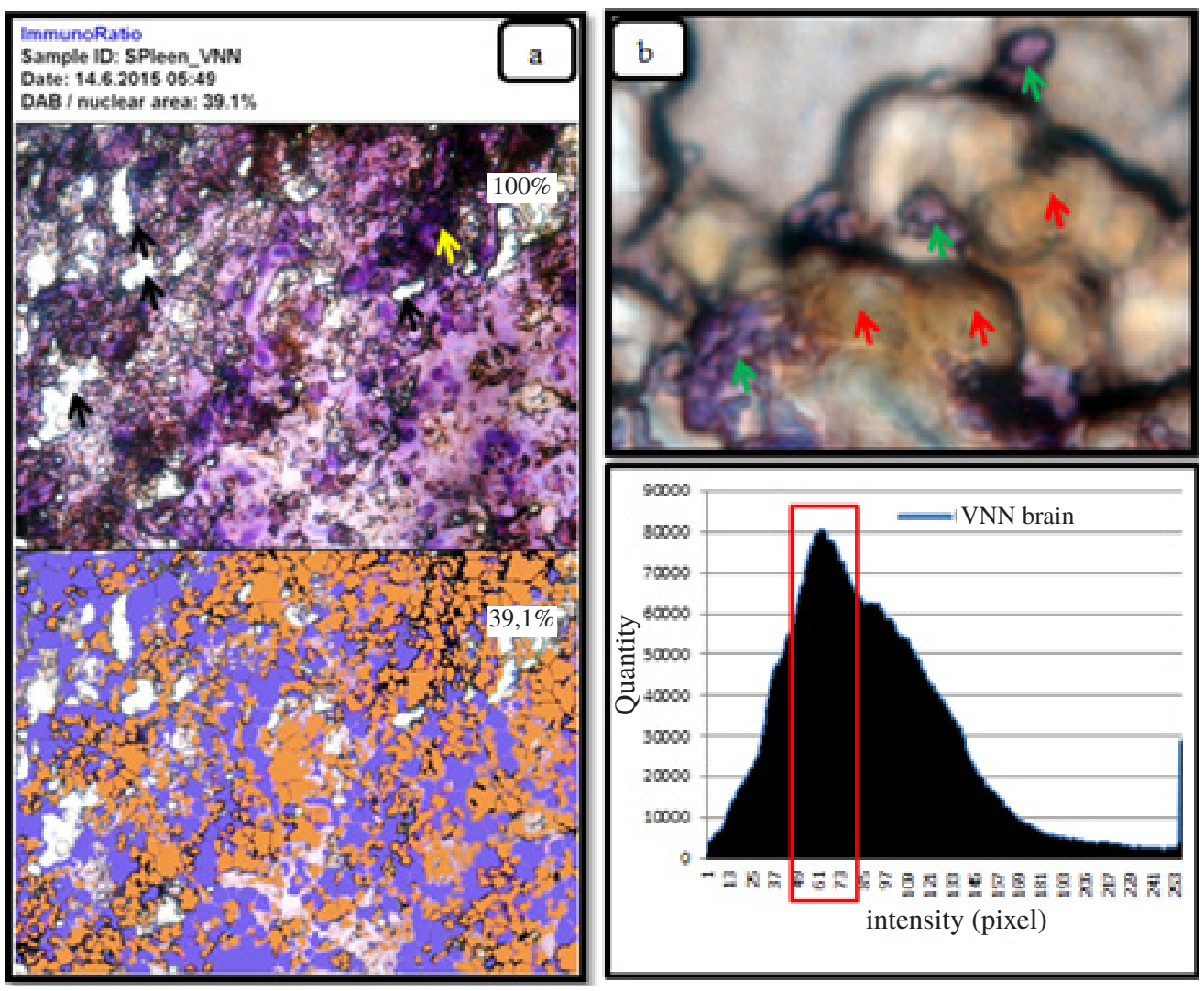

Figure 6. Brain profile of viral nervous necrosis-infected humpback grouper: (a) immunoratio $(39,1 \%)$, (b) immunohistochemistry (IHC) result, (c) histogram (ImageJ). Note: red arrow: $\beta$-actin expression, black arrow: vacuolation, yellow arrow: necrosis, green arrow: apoptosis.
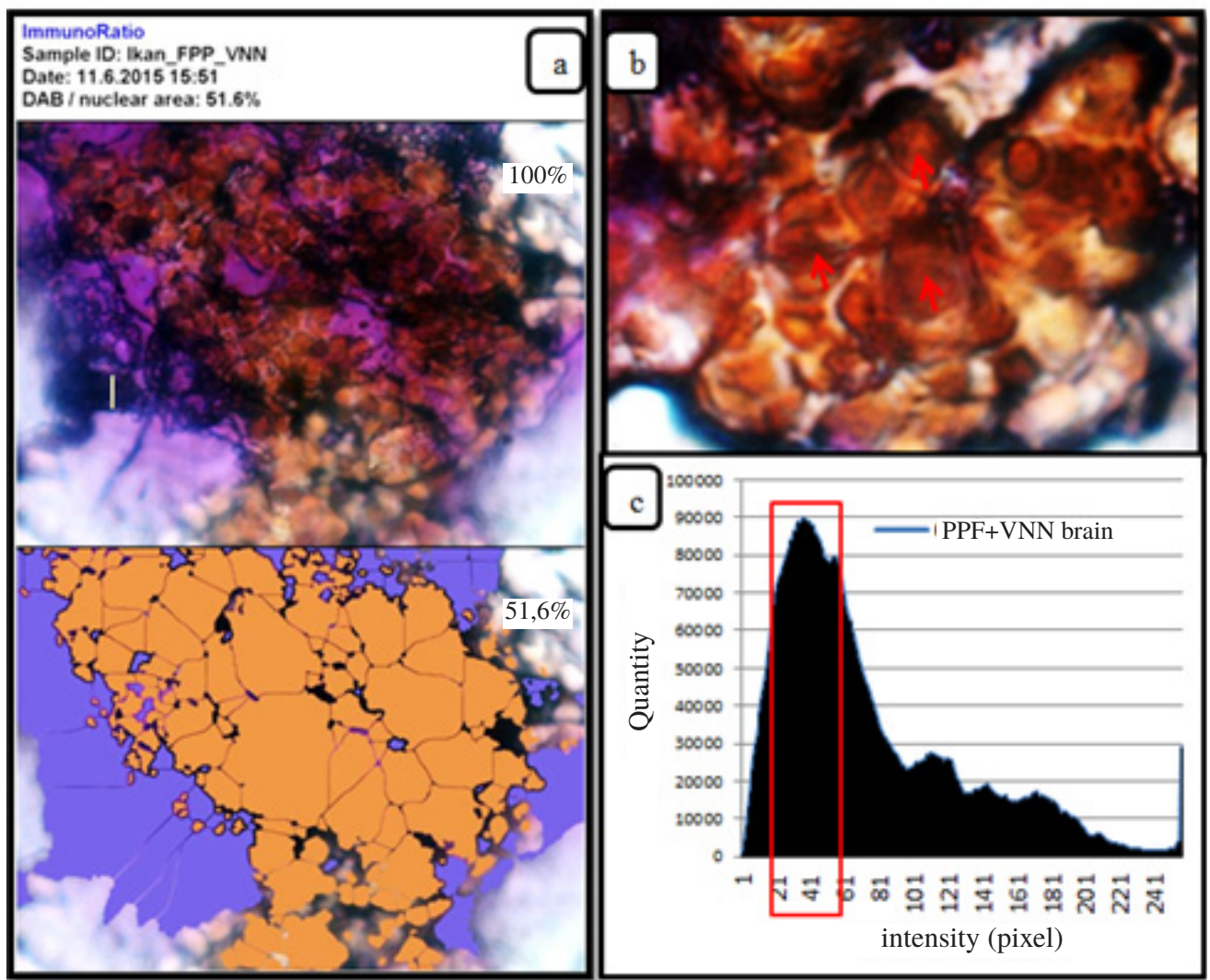

Figure 7. Brain profile of PPF induced and viral nervous necrosis-infected humpback grouper: (a) immunoratio $(51.6 \%)$, (b) immunohistochemistry (IHC) result, (c) histogram (ImageJ). Note: $\beta$-actin expressed throughout the cell (red arrow). 
mainly due to $\beta$-actin effect (Yanuhar, 2015). $\beta$-actin has a vital role in remodeling chromatin group, RNA polymerase complex, and some ribonucleic protein (McDonald et al., 2006). Saha et al. (2006) reported that this gene utilized cytoskeleton actin function to reach the blocking site of virus protein synthesis.

$\beta$-actin increase will also elevate the regulation of gene synthesis and expression. A report by Visa and Percipalle (2010) stated that $\beta$-actin has an essential role in gene expression as a component of chromatin modification complex. In gene expression, $\beta$-actin function was connected to RNA Polymerase I, II, and III (Almuzzaini et al., 2016; Serebryannyy, 2016); Hu et al., 2004). On the contrary, Ye et al. (2008) stated that actin polymer deficiency will cause actin inability to bind with polymerase I, thus the transcription process is not supported.

When infected with VNN without PPF application, the fish showed cell damage e.g. necrosis, vacuolysis, and apoptosis (Figure $6 \mathrm{a}$ and $6 \mathrm{~b}$ ). The increasing $\beta$-actin expression was insufficient to prevent infection. Yuwanita and Yanuhar (2013) stated that VNN infection in humpback grouper damage the brain cells causing necrosis, vacuolization, and hypertrophy. The VNN infected fish died on the second week while fish treated with VNN and PPF survived until the last day of the four week rearing period.

\section{CONCLUSION}

Pigment-protein fraction(PPF) from the marine microalgae Nannochloropsis oculata induced to viral nervous necrosis (VNN) infected humpback grouper Cromileptes altivelis increased the fish $\beta$-actin expression. The increase indicated a reliable immune response against VNN infection. PPF application on humpback grouper culture can be utilized as immunostimulant by increasing immune response in developing antiviral genes to prevent VNN infection.

\section{ACKNOWLEDGEMENTS}

The author would like to express gratitude to the Higher Education Research Program (PUPT BOPTN DIKTI 2016).

\section{REFERENCES}

Almuzzaini B, Sarshad AA, Rahmanto AS, Hansson ML, Von Euler A, Sangfelt O, Visa
N, Farrants AK, Percipalle P. 2016. In $\beta$-actin knockouts, epigenetic reprogramming and rDNA transcription inactivation lead to growth and proliferation defects. The Federation of American Society for Experimental Biology Journal 8: 2860-2873

Ariyanti F. 2015. Kerapu bebek, ikan mewah dengan harga Rp 4 juta per ekor. Liputan6 bisnis. http://bisnis.liputan6.com/ $\mathrm{read} / 2324882 /$ kerapu-bebek-ikan-mewahdengan-harga-rp-4-juta-per-ekor. Diakses 2 Juni 2016.

Basso S, Simionato D, Gerotto C, Segalla A, Giacometti G M, Morosinotto T. 2014. Characterization of the photosynthetic apparatus of the Eustigmatophycean Nannochloropsis gaditana: evidence of convergent evolution in the supramolecular organization of photosystem I. Biochimica et Biophysica Acta Bioenergetic 1837: 306-314.

Bentley CD, Carrol PM, Watanabe W, Riedle AM. 2008. Intensive rotifer production in a pilot-scale continuous culture recirculating system using nonviable microalgae and an ammonia neutralizer. Journal of the World Aquaculture Society 39: 625-635.

Brezski RJ, Monroe JG. 2007. B cell antigen receptor-induced Rac1 activation and Rac1-dependent spreading are impaired in transitional immature B cells due to levels of membrane cholesterol. Journal of Immunology 179: 4464-4472.

Bunnel TM, Burbach BJ, Shimizu Y, Ervasti JM. 2011. $\beta$-actin specifically controls cell growth, migration, and the G-actin pool. Molecular Biology of the Cell 22: 4047-4058

Cao S, Zhang X, Fan X, Qiao H, Liang C, Xu D, Mou S, Wang W, Ye N. 2013. Phylogeny and characterization of Nannochloropsis oceanica var. sinensis var. nov (Eustigmatophyceae), a new oleaginous alga from China. Phycologia 52: 573-577.

Costa JZ, Thompson KD. 2016. Understanding the interaction between Betanodavirus and its host for the development of prophylactic measures for viral encephalopathy and retinopathy. Fish and Shellfish Immunology 53: 35-49.

Helms AJ, Coker JS. 2010. Variability of actin gene expression during tissue regeneration of the earthworm Lumbricus Terrestris. Journal of the North Carolina Academy of Science 126: $138-143$.

Hu P, Wu S, Hernandez N. 2004. A role for beta- 
actin in RNA polymerase III transcription. Genes and Development. 18: 3010-3015.

Irving AT, Wang D, Vasilevski O, Latchoumanin O, Kozer N, Clayton AH, SzczepnyA, Morimoto H, Xu D, Williams BR, Sadler AJ. 2012. Regulation of actin dynamics by protein kinase $\mathrm{R}$ control of gelsolin enforces basal innate immune defense. Immunity 36 : 795-806.

Jönsson F, Gurniak CB, Fleischer B, Kirfel G, Witke W. 2012. Immunological responses and actin dynamics in macrophages are controlled by $\mathrm{n}$-cofilin but are independent from ADF. PLoS ONE 7: e36034.

Jovčevska I, Zupanec N, Kočevar N, Cesselli D, Podergajs N, Stokin CL, Myers MP. 2014. TRIM28 and $\beta$-actin identified via nanobodybased reverse proteomics approach as possible human glioblastoma biomarkers. PLoS ONE 9: e113688.

Khan SA, Tyagi M, Sharma AK, Barreto SG, Sirohi B, Ramadwar M, Gupta S. 2014. Cell-type specificity of $\beta$-actin expression and its clinicopathological correlation in gastric adenocarcinoma. World Journal of Gastroenterology 20: 12202-12211.

Khumaidi A, Maftuch M, Yanuhar U. 2015. Immunohistochemistry of gill and brain infected by Viral Nervous Necrosis (VNN) in Humpback grouper Cromileptes altivelis correlated with beta-actin expression. Journal of Life Science and Biomedicine 5: 127-131.

Komariyah NR. 2014. Ekspresi toll like receptor (TLR) pada ikan kerapu tikus Cromileptes altivelis yang diinduksi protein peridinin chlorophyll cell pigment (PCP) mikroalga Nannochloropsis oculata [Tesis]. Malang: Fakultas Perikanan dan Ilmu Kelautan. Universitas Brawijaya.

Laemmli UK, 1970. Cleavage of structural proteins during the assembly of the head of bacteriophage T4. Nature 227: 680-685.

Male D, Brostoff J, Rott D, Roitt I. 2012. Immunology, $8^{\text {th }}$ ed. London: Saunders.

McDonald D, Carrero G, Andrin C, de Vries G, Hendzel MJ. 2006. Nucleoplasmic $\beta$-actin exists in a dynamic equilibrium between low-mobility polymeric species and rapidly diffusing populations. Journal of Cell Biology 172: 541-552.

Pollard TD, Cooper JA. 2009. Actin, a central player in cell shape and movement. Science 326: 1208-1212.

Ringo J, Sharon G, Segal D. 2011. Bacteria- induced sexual isolation in Dorsophila. Fly 5: 310-315

Saha S, Sugumar P, Bhandari P, Rangarajan PN. 2006. Identification of Japanese encephalitis virus-inducible genes in mouse brain and characterization of GARG39/IFIT2 as a microtubule-associated protein. Journal of General Virology 87: 3285-3289.

Serebryannyy LA, Parilla M, Annibale P, Cruz CM, Laster K, Gratton E, Kudryashov D, Kosak ST, Gottardi CJ, de Lanerolle P. 2016. Persistent nuclear actin filaments inhibit transcription by RNA polymerase II. Journal of Cell Science 129: 3412-3425

Spencer VA. 2011. Actin-towards a deeper understanding of the relationship between tissue context, cellular function and tumorigenesis. Cancer 3: 4269-4280.

Sukenik A, Livne A, Neori A, Yacobi YZ, Katcoff D. 1992. Purification and characterization of a light-harvesting chlorophyll-protein complex from the marine eustigmatophyte Nannochloropsis sp. Plant Cell Physiology 33: 1041-1048.

Takaichi S. 2011. Carotenoids in algae: distributions, biosyntheses and functions. Marine Drugs 9: 1101-1118.

Tang W, You W, Shi F, Qi T, Wang L, Djouder Z, Liu W, Zengc X. 2009. RNA helicase A acts as a bridging factor linking nuclear $\beta$-actin with RNA polymerase II. Biochemical Journal 420: 421-428.

Towbin H, Stahelin T, Gordon J. 1979. Electrophoretic transfer of protein from polyacrilamid gels to nitrocellulose sheets. Proceedings of the National Academy of Sciences 76: 4350-4354.

Tuominen VJ, Ruotoistenmäki S, Viitanen A, Jumppanen M, Isola. 2010. ImmunoRatio: a publicly available web application for quantitative image analysis of estrogen receptor (ER), progesterone receptor (PR), and Ki-67. Breast Cancer Research 12: R56.

Varghese F, Bukhari AB, Malhotra R, De A. 2014. IHC profiler: An open source plugin for the quantitative evaluation and automated scoring of immunohistochemistry images of human tissue samples. PLoS ONE 9: e96801.

Vascotto F, Lankar D, Faure-André G, Vargas P, Diaz J, Le Roux D, Yuseff MI, Sibarita JB, Boes M, Raposo G, Mougneau E, Glaichenhaus N, Bonnerot C, Manoury B, Lennon-Duménil AM. 2007. The actin-based motor protein myosin II regulates MHC class II trafficking 
and BCR-driven antigen presentation. Journal of cell Biology 176: 1007-1019.

Visa N, Percipalle P. 2010. Nuclear functions of actin. Cold Spring Harbor PeRPSectives Biology 2: a000620.

Weis VM, Verde EA, Reynold WS. 2002. Characterization of a short form peridininchlorophyll-protein (PCP) cDNA and protein from the symbiotic Dinoflagellate Symbiodinium muscatinei (Dynuphyceae) from the sea anemone Anthopleura elegantissima (Cnidaria). Journal of Phycology 38: 157-163.

West MA, Robert P, Wallin A, Matthews SP, Svensson HG, Zaru G, Hans-Gustaf L, Prescott AR, Watts. 2004. Enhanced dendritic cell antigen capture via toll-like receptor-induced actin remodeling. Science 305: 1153-1157.

Yanuhar U. 2015. Effects of pigment-protein fraction from Nannocloropsis oculata on TNF $\alpha$ and IL-6 which act as an antiinflammatory against viral nervous necrosis (VNN) infection. Procedia Chemistry 14: 437-443.

Yanuhar U, Nurdiani R, Hertika AMS. 2011. Potency of Nannochloropsis oculata as antibacterial, antioxidant and antiviral on humpback grouper infected by Vibrio alginolyticus and viral nervous necrotic. Journal of Food Science and Engineering 1: 323-330.
Yanuhar U. 2009. The influence of supply of bioactive extract Nannochloropsis oculata to dose of free radicals in the humpback grouper Cromileptes altivelis that was infected by Vibrio alginolyticus. Jurnal Ilmiah Perikanan dan Kelautan 1: 185-191.

Yanuhar U, Gusman E, Arfiati D. 2012. The exposure immunogenic protein of viral nervous necrotic on humpback grouper that influences to proliferation and expression of immune cells (Interferon $\gamma$ and NFKb Cell). Advances in Environmental Biology 6: 388396.

Ye J, Zhao J, Hoffmann-Rohrer U, Grummt I. 2008. Nuclear myosin I acts in concert with polymeric actin to drive RNA polymerase I transcription. Genes Development 22: 322330.

Yuseff MI, Reversat A. 2011. Polarized secretion of lysosomes at the B cell synapse couples antigen extraction to processing and presentation. Immunity 35: 361-374.

Yuwanita R, Yanuhar U. 2013. Pathognomonic of viral nervous necrotic (VNN) virulence on larvae of humpback. Advances in Environmental Biology 7: 1074-1081.

Zheng B, Han M, Bernier M, Wen JK. 2009. Nuclear actin and actin-binding proteins in the regulation of transcription and gene expression. Federation of European Biochemical Societies Journal 276: 2669-2685. 